\title{
Lisa DeBruyne \\ Treatment of malignancy by direct gene transfer of a foreign MHC class I molecule
}

\author{
Received: 6 August 1996 / Accepted: 20 September 1996
}

Key words Gene transfer $\cdot$ MHC class $\mathrm{I} \cdot \mathrm{V} \beta \cdot \mathrm{T}$ cells

\section{Introduction}

Despite our increasing understanding of the molecular basis of cancer, many malignancies remain resistant to established forms of treatment. However, some cancers, such as melanoma, are relatively more responsive to modulation of immune function, possibly because the immune system can be induced to recognize mutant gene products that arise in these cells. Depending on treatment, $10 \%-20 \%$ of melanomas respond to some form of immunotherapy [42, 45, 54, $83,84]$. Conventional approaches to immunotherapy have utilized adjuvants, cytokines, or adoptive transfer of immune cells that have shown promise in animal models [13, $79,92,94,106,107]$ and in humans [44, 55, 80, 81]. More recently, molecular genetic interventions have been designed in an attempt to improve the efficacy of immunotherapy $[63,64,78,82]$. The definition of tumor-associated genetic mutations has heightened interest in cancer as a target for gene therapy. Animal models have shown that genes encoding cell-surface antigens [72], immunomodulatory cytokines $[19,98]$ or T-cell-costimulatory molecules [12, 100] can enhance the immune response to tumors. Based on these animal studies, several human gene transfer protocols have been designed to monitor safety, toxicity, gene expression, and the immune response to tumors [7, 10, 22, 28, $35,51,63,70,87,89,102]$.

Tumor cell growth can be directly related to their ability to evade the immune system. Tumors may actively inhibit the immune response by producing immunosuppressive factors [26, 69, 85], or by inducing the development of

This article forms part of the Symposium in Writing on Therapeutic Cancer Vaccines published in this issue (Vol. 42, No. 3) of the journal

\section{A. DeBruyne}

Department of Surgery, A560 MSRBII, University of Michigan Medical Center Ann Arbor, MI 48109, USA regulatory cells with suppressive activity $[3,4,11]$. Since tumors arise from self tissue, they may be poorly immunogenic and therefore may be viewed as self by the immune system. Likewise, tumor cells may have a decreased capacity to present antigen because of deficiencies in $\beta 2$ microglobulin, peptide transporter, or proteosome expression, all of which are requisite for effective class I antigen presentation [41, 76, 99]. Genetic modification of tumors shows promise as a therapeutic modality to increase the antigenicity of tumor cells as well as to enhance the production of immunopotentiating cytokines [7, 22, 27, $30,53,64,89]$. At the University of Michigan, Nabel and colleagues have developed a gene-transfer approach that utilizes the immunogenicity of a transplantation antigen to stimulate immune reactivity [63-66].

It has long been appreciated that the frequency of alloantigen-reactive $\mathrm{T}$ cells is quite high, even in naive animals that have not been previously immunized with alloantigens [52]. Since T cells with the potential to respond to foreign MHC molecules are dispersed throughout the immune system at frequencies 100-1000 times greater than that of $\mathrm{T}$ cells responsive to nominal antigen, alloantigens are potent immunogens. Alloantigen-reactive $\mathrm{T}$ cells may directly recognize intact MHC proteins (direct recognition), or may respond to allogeneic MHC peptides that have been processed and presented in the context of self-MHC proteins by autologous antigen-presenting cells (indirect recognition) [91]. Direct recognition is likely the dominant pathway by which CD8+CTL respond to allogeneic class I MHC, while the indirect pathway may play an important role in stimulating regulatory $\mathrm{CD} 4+$ helper $\mathrm{T}$ lymphocytes. Hence, gene transfer of a foreign MHC class I molecule has the potential of stimulating both effector and regulatory arms of the immune response (Fig. 1). Thus, Nabel et al. proposed to deliver an allogeneic MHC class I gene into tumors to enhance the antitumor immune response [63-66].

In these studies, Nabel and collaborators utilized a novel approach for delivering genes into tumors [63-66]. This approach relies on the direct transmission of recombinant genes into established tumors in vivo to modify them 
Fig. 1 An allogeneic MHC class I molecule is introduced into tumors by direct gene transfer to enhance the antitumor immune response

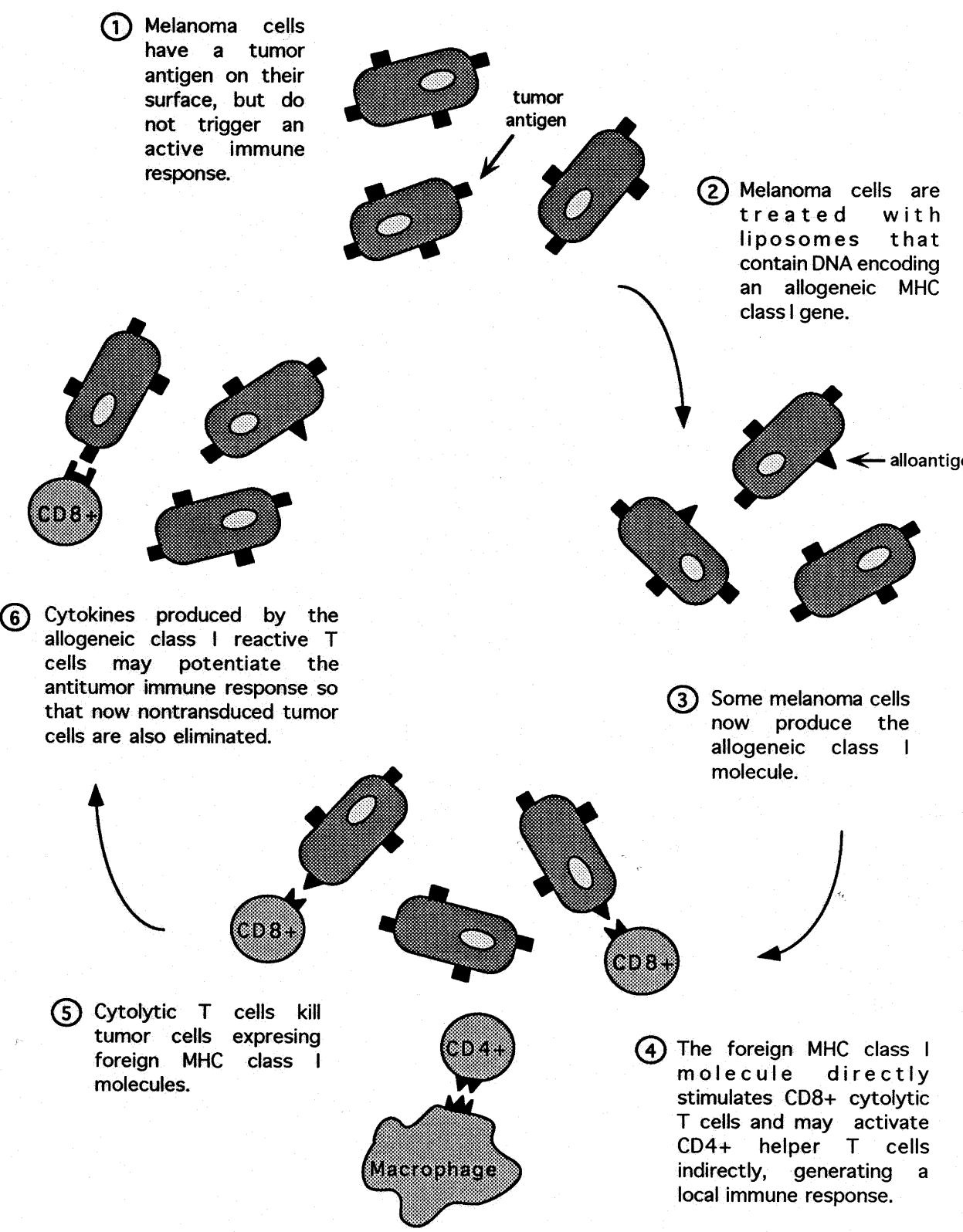

genetically as they grow in situ. In many gene-transfer models, tumor cells are cultured and transfected in vitro, then reintroduced into the host. Disadvantages of this approach include the need to establish an autologous tumor cell line for each patient, and the potential risk of altering the tumor by in vitro manipulation. In studies at the University of Michigan, the vector is transferred in vivo directly into tumor cells using intratumoral injection or, in some cases, catheter delivery [63-66]. The direct in situ transfer of an immunostimulatory gene into the tumor provides an alternative therapeutic approach, which is not subject to these limitations. In addition, direct gene transfer may be performed immediately, thereby avoiding any delay in treatment posed by the need to establish and transfect tumor lines in vitro. Thus, in ongoing studies, tumor nodules are directly injected with a vector encoding an allogeneic MHC class I molecule.

\section{Experimental systems}

Direct gene transfer was initially tested in animal models using both retroviral vectors and DNA/liposome complexes $[21,59]$. Utilizing a $\beta$-galactosidase reporter plasmid, recombinant gene expression could be readily detected after in vivo injection of DNA/liposome complexes or retroviral vectors in established murine CT26 tumors [72]. Further, gene expression was estimated to be $0.1 \%-1.0 \%$ at the sites of injection [29]. Thus, it was demonstrated that it was possible to transfer genes in situ directly into established tumors.

In an effort to show that a specific biological response could be induced at sites of recombinant gene transfer, an allogeneic class I gene was directly injected into BALB/ $\mathrm{c}\left(\mathrm{H}-2 \mathrm{~K}^{\mathrm{d}}\right)$-tumor-bearing mice [72]. The foreign MHC 
class I gene $\mathrm{H}-2 \mathrm{~K}^{\mathrm{s}}$ was introduced into CT26 mouse colon adenocarcinoma $\left(\mathrm{H}-2 \mathrm{~K}^{\mathrm{d}}\right)$ tumors in vivo in an effort to stimulate tumor rejection. The $\mathrm{H}-2 \mathrm{~K}$ class I antigen was chosen because it is strongly expressed on most tissues and can mediate an allogeneic rejection response. The $\mathrm{H}-2 \mathrm{~K}^{\mathrm{s}}$ gene or the control ( $\beta$-galactosidase reporter gene) was introduced directly into tumors using either a retroviral vector or DNA-liposome complexes. Mice receiving intratumor injections showed evidence of recombinant DNA by polymerase chain reaction (PCR) analysis and no evidence of inflammation or toxicity was detected.

Both the $\mathrm{H}-2 \mathrm{~K}^{\mathrm{s}}$ retroviral vector and DNA/liposome complexes were found to signal the immune system to mount a response. Lymphocytes derived from mice bearing the $\mathrm{H}-2 \mathrm{~K}^{\mathrm{s}}$, , but not the $\beta$-galactosidase-transduced tumors, demonstrated a cytolytic response to $\mathrm{H}-2 \mathrm{~K}^{\mathrm{s}}$. Most significantly, lymphocytes derived from $\mathrm{H}-2 \mathrm{~K}^{\mathrm{s}}$-, but not $\beta$-galactosidase-transduced animals, recognized and lysed unmodified CT26 cells. Thus, transfer of the $\mathrm{H}-2 \mathrm{~K}^{\mathrm{s}}$ gene induced immune reactivity against genetically unmodified tumor cells. Lysis was inhibited by an antibody against CD8, which blocks cytotoxic $\mathrm{T}$ lymphocytes (CTL) but not lymphokine-activated killer or antibody-dependent cellmediated cytotoxicity cell killing. Further, nude mice bearing CT26 showed no reduction in tumor growth after $\mathrm{H}-2 \mathrm{~K}^{\mathrm{s}}$ injections, compared to controls. Thus, these data suggest that this immune response was T-cell-mediated, implying that immune stimulation by the alloantigen $\mathrm{H}-2 \mathrm{~K}^{\text {s }}$ induced specific $\mathrm{T}$ cell recognition of tumor-associated antigens not normally seen by the immune system. Specificity of tumor protection was evaluated in MCA-106(H-2Kb)-tumor-bearing mice treated with intratumoral injections of $\mathrm{H}-2 \mathrm{~K}^{\mathrm{s}}$ liposome complexes. Secondary inoculation at distant sites with parental MCA 106 tumor produced growth in only $20 \%$ of the mice whereas the unrelated syngeneic tumor B16BL/6 melanoma grew in $100 \%$ of the animals.

$\mathrm{H}-2 \mathrm{~K}^{\mathrm{s}}$-transduced tumors in unsensitized animals showed attenuation of growth, whereas, no antitumor effect was seen in unmodified or $\beta$-galactosidase-transduced tumor animals. In an attempt to optimize the antitumor response, mice were preimmunized with irradiated CT26 $\mathrm{H}-2 \mathrm{~K}^{\mathrm{s}}$ tumor cells and given earlier and/or more frequent injections of vector. These strategies improved survival and attenuated tumor growth in contrast to $\beta$-galactosidasetransduced tumors where there was no difference compared with unmodified animals. Full tumor regression was achieved in some cases by increasing the number of injections and by delivery of $\mathrm{H}-2 \mathrm{~K}^{\mathrm{s}}$ into tumors at an earlier stage. In addition, presensitization with CT26 H$2 \mathrm{~K}^{\mathrm{s}}$, followed by treatment with $\mathrm{H}-2 \mathrm{~K}^{\mathrm{s}}$ DNA/liposome complex proved effective against MCA $106 \mathrm{H}-2 \mathrm{~K}^{\mathrm{b}}$ fibrosarcoma. Thus, presentation of $\mathrm{H}-2 \mathrm{~K}^{\mathrm{s}}$ on a heterologous allogeneic cell line enhanced protection against a syngeneic tumor transduced in vivo with $\mathrm{H}-2 \mathrm{~K}^{\mathrm{s}}$.

The most important finding of these animal studies was that stimulation of the immune system by the foreign MHC class I antigen caused sensitization to otherwise unrecognized tumor antigens and provided a therapeutic effect for established malignancy in vivo. Since these studies demon- strated that direct gene transfer with an allogeneic class I molecule can provide a therapeutic effect against established malignancies, a human phase I clinical trial utilizing this approach was initiated at the University of Michigan to treat metastatic melanoma [63].

The initial animal studies demonstrated that DNA/liposome complexes or retroviral vectors can efficiently mediate direct gene transfer. Although modified viruses have served as useful vectors for ex vivo gene transfer, their ability to recombine or interact with endogenous viruses has raised concerns regarding safety for in vivo gene transfer with human patients. In contrast, it has been demonstrated that nonviral vectors, such as DNA/liposome complexes, can mediate gene transfer into tissues in vivo and provides a safer alternative $[21,59,60,64,95]$. The use of liposomes eliminates the need to synthesize viral vectors, establish subclones of producer cell lines, and assess viral titers and the presence of replication-competent helper virus. In addition, both DNA and liposomes can be stored stably for months. Thus, DNA/liposome complexes offer several advantages over viral vectors and are a safer alternative for human gene therapy.

\section{Clinical trials}

By utilizing DNA/liposome complexes, human melanoma nodules were genetically transduced in situ to express the foreign MHC class I molecule (HLA-B7) in an attempt to induce an antitumor immune response [64]. In the first of two phase I clinical trails, five HLA-B7-negative patients with stage IV melanoma refractory to conventional therapies were enrolled on the basis of the guidelines of the clinical protocol [63]. Each patient tolerated the treatment well with no acute complications. The eukaryotic expression vector plasmid utilized in this trial (pHLA-B7) was prepared by insertion of HLA-B7 cDNA into the Rous sarcoma virus $\beta$-globin plasmid $[32,61]$. DNA/liposome complexes were prepared immediately prior to intratumor injection by adding lactated Ringer's solution to pHLA-B7, then combining it with the lipid dioleoyl phosphatidyletha-

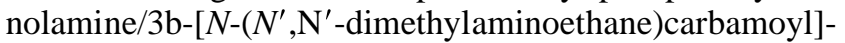
cholesterol liposome. Patients received a treatment schedule that consisted of either a single injection or a series of three injections of DNA/liposome complex (cumulative dose 0.29-2.58 $\mu \mathrm{g}$ DNA) into a single melanoma nodule.

One of the primary goals of the first clinical trial was to determine whether there was any toxicity associated with DNA/liposome gene therapy $[63,64]$. To monitor the potential toxicity of the DNA/liposome treatment, biochemical, hematological, and hemodynamic parameters were evaluated along with vital signs and cardiac rhythm. Analysis of serum biochemical parameters revealed no pattern of systemic abnormalities in these patients. Myocardial abnormalities were not detected by analysis of creatine kinase or its isoenzymes in the serum of treated patients, and no electrocardiographic changes or arrhythmias were noted. A major question regarding the future potential of 
this gene-delivery approach in humans was whether an immune response would be generated to DNA. Such a response or the formation of antibodies to DNA could induce resistance to treatment or signal the development of autoimmunity. In these studies, there were no detectable increases in anti-DNA antibodies and no clinical evidence of autoimmunity. Thus, it appears that foreign DNA is not highly immunogenic in vivo and that the immune response is unlikely to limit in vivo gene transfer by DNA/liposome complexes.

Injected tumor nodules were biopsied 3-7 days after gene transfer and tissue was analyzed for the presence of plasmid DNA, mRNA coding for HLA-B7, and expression of HLA-B7 protein [64]. RNA encoding HLA-B7 was detected by PCR after incubation with reverse transcriptase but not in its absence. Further, HLA-B7 protein expression was confirmed in biopsy samples by immunohistochemistry. The recombinant protein was detected at frequencies ranging from $1 \%$ to $10 \%$ of tumor cells near the site of injection. Also, it is important to note that plasmid was not detected at any time in the blood following gene transfer, suggesting that the DNA remained localized to the site of injection.

Cytolytic $\mathrm{T}$ cell responses were evaluated to determine whether gene transfer resulted in altered antitumor immunity [64]. Tumor-specific CTL were detected in both the peripheral blood and from tumor-infiltrating lymphocytes (TIL) in patients evaluated after gene transfer. These CTL lysed autologous melanoma specifically and in a dosedependent fashion. Although there were no pretreatment samples available for a comparison, the ability to detect $\mathrm{T}$ cells specific for melanoma in the peripheral blood is unusual and thus likely to be treatment-related. Further, in 1 patient where a pretreatment sample was available, a fivefold increase in the frequency of HLA-B7-reactive CTL precursors was detected after treatment. These findings suggest that expression of the foreign MHC gene after gene transfer altered the reactivity of the immune system in these patients.

In regard to tumor growth, 1 patient showed complete regression of a HLA-B7-treated cutaneous nodule [64]. In addition, over the same period, metastatic lesions at distant sites also displayed complete regression, including lesions on the upper and lower back, upper arm, abdomen, and a pulmonary nodule. It is interesting to note that the patient whose tumors regressed after treatment received injections in cutaneous nodules, whereas, in the other patients, metastatic lymph nodes were treated. Thus, lymph node replacement by tumor may be associated with a greater degree of immunosuppression, or dermal dendritic cells may provide more efficient antigen presentation and immune stimulation. Therefore, on the basis of these findings, a second phase I clinical trial was initiated in which pHLAB7 was delivered by direct injection into cutaneous tumor nodules.

The first clinical trial determined the feasibility and safety of directly transferring genes into humans. In addition, it provided important information regarding the dosage of DNA and lipid required for expression and biolo- gical effect. Thus, on the basis of findings of the first study, modifications of plasmid and lipid were subsequently designed to improve clinical efficacy. The improved plasmid vector included the gene encoding $\beta 2$-microglobulin, with which class I MHC genes normally associate. Ordinarily, these two gene products are co-transported to the cell surface with both molecules being required in order to express a stable class I protein on the cell $[43,77]$. Loss of $\beta 2$-microglobulin is one mechanism by which tumor cells lose stable class I expression, thus becoming less immunogenic, and are able to evade the immune system [17, 25, 36, $38,77,104]$. Several tumor cell lines that exhibit low levels of class I MHC proteins have been shown to be less oncogenic when expression vectors encoding the relevant class I MHC antigen are introduced into them [34, 37, 48, 97, 103]. Further, Nabel et al. have found that the inclusion of the $\beta 2$-microglobulin gene on the same plasmid as HLAB7 allows for the expression of class I in otherwise resistant cells and improves expression in other cells, thus, overcoming a potential mechanism of resistance [65].

In addition to an improved expression vector, a new cationic lipid formulation was developed (1,2-dimyristyloxypropyl-3-dimethylhydroxyethyl-ammonium bromide utilized with dioleoyl phosphatidylethanolamine [20, 86]. This new formulation improved expression up to tenfold compared to the previous formulation in in vitro transfection studies. What is more important, this formulation does not aggregate at high concentrations, and this characteristic allows higher absolute concentrations of DNA and liposomes to be introduced into experimental animals without toxicity. Thus, in the second phase I clinical trial, much higher doses (more than 100-fold) were able to be administered without toxicity $[65,66]$.

Utilizing the improved vector and lipid, the second study enrolled 10 HLA-B7-negative patients with stage IV melanoma, who were all unresponsive to standard treatments $[65,66]$. Patients were divided into four groups, each of which received a different dose of DNA/liposome complex $(3,30,100$, or $300 \mu \mathrm{g}$ DNA) three times biweekly for a total of three treatments. To monitor the potential toxicity of the DNA/liposome treatment, biochemical, hematological and hemodynamic parameters were again evaluated. No abnormalities were found in the acute period (3-7 days) or up to 2 months after the initial gene transfer. As in the first study, no increases in anti-DNA antibodies were detected in patients and there was no clinical evidence of autoimmune phenomena. Thus, these data support the previous observations that DNA is not highly immunogenic in vivo in humans and an immune response to DNA/liposome complexes is unlikely to limit direct gene transfer with this vector or other forms of DNA.

Patient tumor samples were obtained by core needle biopsies before and at 1-3 days after intratumoral injection of HLA-B7 DNA/liposome complexes [65, 66]. Reverse transcriptase (RT)/PCR was performed on biopsy samples of injected tumor to confirm recombinant HLA-B7 gene expression within treated tumors, and blood samples obtained immediately before and at multiple times after injection were analyzed for the presence of plasmid DNA 
by PCR. In these patients, plasmid DNA was not detected at any time in the blood following gene transfer, indicating that the DNA remained localized to the site of injection. In addition, RNA coding for HLA-B7 was detected by PCR after incubation with reverse transcriptase but not in its absence, and HLA-B7 protein expression was verified in biopsy tissue by immunohistochemical staining. Similar to the first study, recombinant protein was detected at frequencies ranging from $1 \%$ to $10 \%$ of tumor cells near the site of injection $[64,66]$. Thus, it was demonstrated that gene expression can be consistently achieved without toxicity by this method of gene transfer.

To determine whether the introduction of a foreign MHC gene could alter the $\mathrm{T}$ cell response to tumors, tumor biopsy samples were analyzed for the presence of infiltrating T cells before and after gene transfer [66]. Immunostaining with $\alpha \mathrm{CD} 3$ in tumor nodules revealed $\mathrm{CD}^{+}$cells at the margins of tumors with relatively few cells within the parenchyma before treatment. After gene transfer, an increase in tumor-infiltrating lymphocytes was detected. In cases where tumor growth was not affected, this pattern of infiltration was not maintained. Biopsy samples from a patient who responded to treatment were further investigated by immunostaining for markers of lymphocyte activation. Prior to gene transfer, there were numerous HLADR-positive dendritic cells in and around melanoma cells, with fewer than $10 \%$ expressing the costimulatory molecules CD80 or CD86. After gene therapy, the injected melanoma sites contained dendritic cells in and around the tumor that were HLA-DR-positive, and numerous peritumoral dendritic cells were seen that were CD80and CD86-positive. CD80 (B7.1) and CD86 (B7.2) are important costimulatory molecules necessary for $\mathrm{T}$ cell activation [1, 40, 101]. Thus, the finding of increased CD80 and CD86 expression, along with increased infiltration of $\mathrm{CD}^{+}$cells in treated tumors, suggested that expression of a foreign MHC gene by direct gene transfer may have enhanced the immune response to tumors in some patients.

In an effort to evaluate altered $\mathrm{T}$ cell tumor immunity, limiting-dilution analysis was utilized to quantify autologous tumor-specific CTL in the blood of patients, as well as in TIL populations derived from tumor before and after HLA-B7 gene transfer [66]. The frequency of autologous tumor-specific CTL was quantified in the peripheral blood of 5 evaluable patients. Of the 5 patients, 4 had rare to undetectable frequencies before treatment, and 4 remained unchanged following gene transfer. However, it should be noted that 1 individual did show an increase after treatment, but the cytolytic activity of these cells was weak. Hence, in most patients, HLA-B7 gene transfer did not markedly alter the frequency of autologous tumor-specific CTL in the peripheral blood, as might be expected from other model systems [8].

Cytolysis assays revealed that TIL populations generally showed a high degree of specific lysis of autologous but not heterologous melanoma or natural killer target cells in vitro [66]. TIL obtained prior to treatment possessed weak to negative cytolytic activity for autologous tumor; however, the lytic activity of post-treatment-derived TIL was increased in the patients evaluated. In addition, the frequencies of CTL precursors within these TIL populations were determined by limiting-dilution analysis. In the few patients evaluated, gene transfer increased the CTL precursor frequency of autologous tumor-reactive TIL. Hence, the frequency of CTL precursor cells paralleled the direct lytic activity of TIL in these patients. These findings suggest that HLA-B7 gene transfer may result in an adjuvant effect where an immune response is generated to parental tumor antigens.

In regard to tumor growth, 1 patient showed partial regression $(50 \%)$ of a treated nodule [66]. In this patient, at least one metastatic lesion at a distant site (inguinal lymph node mass) displayed a similar partial regression over the same period. However, three other distant sites in this same patient showed no regression. When one of these latter tumor nodules was subsequently treated by HLA-B7 gene transfer, reduction in tumor size was observed, although to a lesser degree than for the first lesion $(10 \%-20 \%)$. Together, these data suggest that introduction of the HLA-B7 gene may lead in some cases to antitumor effects at the treatment site and at some distant site of disease.

Since this 1 patient showed evidence of local and systemic responses to HLA-B7 gene transfer, and TIL cultures showed specific cytolytic activity against autologous tumors, gene transfer was combined with immunotherapy in this patient. TIL obtained from tumor nodules that had received injections with HLA-B7 DNA/liposome complexes were expanded and characterized. These TIL cultures mediated tumor-specific lysis of autologous tumor in standard cytotoxic assays. In addition, these TIL demonstrated significantly enhanced release of granulocytemacrophage-colony-stimulating factor (GM-CSF), interferon $\gamma$ (IFN $\gamma)$ and tumor necrosis factor $\alpha$ (TNF $\alpha)$ in response to autologous tumor relative to TIL obtained prior to HLA-B7 gene transfer [66]. Several studies have reported that tumor-specific release of cytokines by immune lymphoid cells correlates with therapeutic efficacy in adoptive-transfer systems [2, 5, 31, 88]. Thus, approximately 1011 cells were adoptively transferred back to the patient and this was followed by interleukin-2 (IL-2) infusion. Following two TIL treatments, this patient manifested a complete regression of residual disease and this remission has persisted now for more than 1 year after the initial treatment.

Considering that HLA-B7 gene transfer resulted in enhanced CTL and cytokine production in response to autologous, nontransduced tumor, it was important to address whether the enhanced antitumor response was due to the expansion or differentiation of cells that existed before treatment, or if it reflected recruitment of additional $\mathrm{T}$ cell populations. Since distinct T cells express different $\mathrm{T}$ cell receptors which impart distinct antigen specificities, these cells may be identified by virtue of $\mathrm{V} \beta$ expression. Thus, to address whether the enhanced antitumor response was due to preexisting cells or newly recruited cells, TIL V $\beta$ expression was evaluated [15]. 


\section{T cell receptor $\mathrm{V} \beta$ expression by TIL}

TIL generated from melanoma lesions are primarily CD3+ $\mathrm{T}$ cells that express an $\alpha / \beta \mathrm{T}$ cell receptor [73]. Antigen specificity is imparted by rearrangement of the variable (V), diversity (D), and joining ( $\mathrm{J}$ ) segments for the $\beta$ locus and of $\mathrm{V}$ and $\mathrm{J}$ segments of the $\alpha$ locus [56]. Random combinations of these segments as well as imprecise $\mathrm{V}(\mathrm{D}) \mathrm{J}$ joining and the addition of $\mathrm{N}$-region nucleotides generates $\mathrm{T}$ cell receptor diversity. Several reports have documented restricted usage of $\mathrm{V} \beta$ elements by TIL in melanoma [24, 75, 90, 96] and other carcinomas, including renal, lung, and ovarian carcinoma [6, 33, 71]. Published reports indicate that the repertoire of $\mathrm{T}$ cells that infiltrate tumors is diverse [9, 23], though certain clones may be expanded in situ [24, 33, 50, 75, 105]. Selection for dominant $\mathrm{T}$ cell clones occurs in TIL cultures, and the presence of IL-2 in these cultures favors expansion of T cells that were activated in vivo.

In our studies, TIL were isolated from cutaneous melanoma biopsies before and after HLA-B7 gene transfer, expanded in IL-2 by standard techniques for approximately 4 weeks, and then analyzed for T cell receptor V $\beta$ usage by quantitative RT-PCR [16]. Prior to gene transfer, TIL V $\beta$ usage was found to be highly restricted with only one to four $\mathrm{V} \beta$ families being expressed, and one or two of these families representing more than $90 \%$ of the repertoire. As anticipated, TIL V $\beta$ usage varied among patients expressing different HLA types. However, V $\beta 13$ was over represented in that 6 of 8 patients utilized $V \beta 13$ as a dominant family, regardless of HLA type. Following HLA-B7 gene transfer, TIL V $\beta$ usage was markedly altered: (1) V $\beta$ families that dominated following gene transfer differed from the $\mathrm{V} \beta$ families utilized by TIL prior to treatment, and (2) introduction of the HLA-B7 gene resulted in a more diverse repertoire with an increase in the number of $\mathrm{V} \beta$ families represented. In 2 patients, TIL were evaluated before treatment and from multiple, distinct melanoma nodules following gene transfer. In these 2 patients, a comparison was made between TIL V $\beta$ profiles obtained after treatment from nodules that had been injected with the HLA-B7 gene and those that had been left untreated. Interestingly, the V $\beta$ repertoires of TIL from uninjected nodules following HLAB7 treatment were similar to those of TIL from injected nodules, rather than to those of pretreatment TIL. These data demonstrate a direct immunological effect of foreign MHC gene transfer into human melanoma, and suggest that local expression of an allogeneic MHC molecule generates systemic alterations in the antitumor immune response.

Restricted V $\beta$ usage has been reported for TIL derived from a variety of tumor types [6, 24, 33, 71, 75, 90, 96], though the degree of $\mathrm{V} \beta$ restriction may vary. The highly restricted $\mathrm{V} \beta$ usage by pretreatment TIL in our studies suggests that a limited number of immunodominant tumor antigens were recognized by pretreatment TIL. A major point to emphasize is that HLA-B7 gene transfer altered the repertoire of T cells that surfaced in TIL cultures, indicating that distinct $\mathrm{T}$ cell populations, probably with distinct antigen specificities, were activated in vivo. In most cases, the T cells that dominated pretreatment TIL cultures were replaced following gene transfer, giving rise to a more diverse population. This effect was systemic, in that TIL derived from distant, uninjected nodules from HLA-B7treated patients exhibited similar altered $\mathrm{V} \beta$ profiles. Hence, $\mathrm{T}$ cells induced by HLA-B7 gene transfer have a selective advantage over cells that were initially recovered from pretreatment tumor nodules. The mechanisms responsible for this altered dominance are currently not known, but may include in situ expansion or an enhanced state of activation of these $T$ cells.

The biological consequence of altered $\mathrm{V} \beta$ expression by TIL after HLA-B7 gene transfer is not fully understood. Following gene transfer, both the pHLA-B7-injected and uninjected nodules of one patient underwent partial regression [66]. This patient subsequently received TIL therapy utilizing post-treatment TIL that expressed a heterogeneous $\mathrm{V} \beta$ repertoire. This TIL therapy resulted in complete regression of all melanoma nodules, suggesting potent in vivo antitumor activity of the TIL induced by HLA-B7 gene transfer. It should be noted that this patient's posttreatment TIL expressed the greatest degree of V $\beta$ heterogeneity of all those assessed in this study [15].

Since TIL obtained from distinct, untreated nodules expressed the same altered $\mathrm{V} \beta$ profile as those obtained from nodules that were injected with the HLA-B7 gene, it is unlikely that all cells in these TIL populations are reactive with HLA-B7. Further, HLA-B7 gene transfer increased the ability of TIL to lyse autologous, nontransduced (HLA-B7negative) tumor cells in some patients [66]. It is possible that HLA-B7 gene therapy produces an adjuvant effect, thus stimulating the development of additional tumor-reactive T cells expressing distinct TCR. One hypothesis is that HLA-B7-reactive $\mathrm{T}$ cells respond to the locally expressed alloantigen, which may be presented directly to CD8+ cells, as well as indirectly by infiltrating macrophages to CD4+ cells (Fig. 1). Cytokines produced by these HLA-B7-reactive cells could potentiate and expand the antitumor immune response at several levels: (1) providing help for the development of additional tumor-reactive T cell clones, (2) up-regulating $\mathrm{MHC}$ and therefore antigen expression by tumor cells [18, 93], and (3) increasing antigen-presenting cell recruitment and function within the tumor [16]. Cytokines can participate in the antitumor response whether by a direct action on cell growth or by activating cellular immunity. For example, the cytostatic effects of TNF $\alpha$ $[67,68]$ and lymphotoxin [74] can result in neoplastic cell death. In addition, IFN $\gamma$ markedly increases class I MHC cell-surface expression [46, 47] and synergizes with TNF $\alpha$ in producing this effect $[67,68]$. Further, colonystimulating factors such as G-CSF and GM-CSF activate neutrophils and macrophages to lyse tumor cells directly [14] and IL-2 activates leu19+ NK cells to generate lymphokine-activated killer cells (LAK) capable of lysing autologous, syngeneic or allogeneic tumor cells but not normal cells [39, 49]. Finally, IL-4 also generates LAK cells and acts synergistically with IL-2 in the generation of tumor-specific killer cells [57]. 


\section{In conclusion}

In contrast to most therapies, stimulation of the immune system by a foreign MHC antigen may cause sensitization of otherwise unrecognized tumor antigens and provide a therapeutic effect for established tumors in vivo. Studies utilizing such an allogeneic molecule have demonstrated that a recombinant gene can be directly introduced in vivo and that the gene product is expressed by host cells. The treatment is safe and there is no observed toxicity [63-66]. In addition, these studies have provided insight into mechanisms of generating tumor immunity. The next steps will be to analyze further the mechanisms of the antitumor immune response and to improve its efficacy. Efficacy may be improved by combining gene therapy with other forms of treatment. Gene-transfer approaches could be used in combination with existing treatments such as cytokines or adoptive T cell therapy. In addition, it would be possible to include other genes along with HLA-B7 in future studies. For example, such genes might encode for anti-proliferative agents, cytokines, growth-factor antagonists, or inhibitors of angiogenesis. Another potential improvement would be to deliver recombinant genes to specific sites by catheter in vivo, in an effort to introduce gene products into metastatic lesions and into the tumor microcirculation. This intervention provides the ability to transduce a larger percentage of cells within the tumor in order to achieve greater efficacy of gene expression while, at the same time, minimizing the potential for inadvertent seeding of tumor cells to distant sites. Particularly for the in vivo catheter delivery, it may be appropriate to utilize this approach on malignancies other than melanoma, such as colon carcinoma, renal cell carcinoma, or breast cancer. Early studies using this approach demonstrated that specific reporter genes could be expressed in vivo [58, 59] and subsequent studies have shown that specific biological responses can be induced at sites of recombinant gene transfer via this delivery route $[61,62,72]$.

Although additional patients will be required to confirm the consistency of the antitumor immune response, it is encouraging that patients in separate clinical studies have shown a response to treatment. In addition to the patients described here [63-66], 7 of 14 patients treated at an independent site have shown local regression in response to this gene-transfer procedure [66]. Clearly, further clinical studies are warranted to establish the efficacy of this genedelivery approach for the treatment of melanoma and other cancers. The ability to alter local or regional immune responses by gene transfer may provide an alternative method to eliminate residual disease and complement current immunological treatments for malignancies.

Acknowledgements My contributions to these studies were performed in the laboratory of Dr. D. Keith Bishop who directed these studies in collaboration with Drs. Gary J. Nabel and Alfred E. Chang.

\section{References}

1. Allison JP (1994) CD28-B7 interactions in T-cell activation. Curr Opin Immunol 6: 414

2. Aruga A, Shu S, Chang AE (1995) Tumor-specific GM-CSF and IFN gamma secretion is associated with in vivo therapeutic efficacy of activated tumordraining lymph node cells. Cancer Immunol Immunother 41: 317

3. Awwad M, North RJ (1988) Immunologically mediated regression of a murine lymphoma after treatment with anti-L3T4 antibody: a

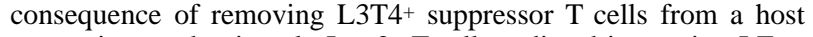
generating predominantly Lyt-2+ T cell-mediated immunity. J Exp Med 168: 2193

4. Baadsgaard O, Salvo B, Mannie A, Dass B, Fox DA, Cooper KD (1990) In vivo ultraviolet-exposed human epidermal cells activate T suppressor cell pathways that involve CD4+CD45RA+ suppressor-inducer T cells. J Immunol 145: 2854

5. Barth RJ Jr, Mule JJ, Spiess PJ, Rosenberg SA (1991) Interferon gamma and tumor necrosis factor have a role in tumor regressions mediated by murine CD8+ tumor-infiltrating lymphocytes. J Exp Med 173: 647

6. Bennett WT, Pandolfi F, Grove BH, Hawes GE, Boyle LA, Kradin RL, Kurnick JT (1992) Dominant rearrangements among human tumor-infiltrating lymphocytes. Analysis of T cells derived from 32 patients with melanoma, lung and renal cell carcinoma. Cancer 69: 2379

7. Berns AJ, Clift S, Cohen LK, Donehower RC, Dranoff G, Hauda KM, Jaffe EM, Lazenby AJ, Levitsky HI, Marshall FF, Mulligan RC, Nelson WG, Owens AH, Pardoll DM, Parry G, Partin AH, Piantadosi S, Simons JW, Zabora JR (1995) Phase I study of non-replicating autologous tumor cell injections using cells prepared with or without GM-CSF gene transduction in patients with metastatic renal cell carcinoma. Hum Gene Ther 6: 347

8. Bishop DK, Ferguson RM, Orosz CG (1990) Differential distribution of antigen-specific helper T cells and cytotoxic T cells after antigenic stimulation in vivo. J Immunol 144: 1153

9. Caignard A, Dietrich PY, Morand B, Lim A, Pannetier C, Leridant AM, Hercend T, Even J, Kourilsky P, Triebel F (1994) Evidence for T-cell clonal expansion in a patient with squamous cell carcinoma of the head and neck. Cancer Res 54: 1292

10. Cascinelli N, Foa R, Parmiani G, Arienti F, Belli F, Bernengo MG, Clemente C, Colombo MP, Guarini A, Illeni MT, Masheroni L, Melani C, Prada A, Sule-Suso J (1994) Active immunization of metastatic melanoma patients with IL-4 transduced, allogeneic melanoma cells. Hum Gene Ther 5: 1059

11. Chakraborty NG, Twardzik DR, Sivanandham M, Ergin MT, Hellstrom KE, Mukherji B (1990) Autologous melanoma-induced activation of regulatory $\mathrm{T}$ cells that suppress cytotoxic response. J Immunol 145: 2359

12. Chen L, Ashe S, Brady WA, Hellstrom I, Hellstrom KE, Ledbetter JA, McGowan P, Linsley PS (1992) Costimulation of antitumor immunity by the B7 counterreceptor for the T lymphocyte molecules CD28 and CTLA-4. Cell 71: 1093

13. Chou T, Chang AE, Shu S (1988) Generation of therapeutic $\mathrm{T}$ lymphocytes from tumor-bearing mice by in vitro sensitization: culture requirements and characterization of immunologic specificity. J Immunol 140: 2453

14. Clark SC, Kamen R (1987) The human hematopoietic colonystimulating factors. Science 236: 1229

15. DeBruyne LA, Chang AE, Cameron MJ, Yang ZY, Gordon D, Nabel EG, Nabel GJ, Bishop DK (1996) Direct transfer of a foreign MHC gene into human melanoma alters T cell receptor V $\beta$ usage by tumor infiltrating lymphocytes. Cancer Immunol Immunother 43: 49

16. Dranoff G, Jaffee E, Lazenby A, Golumbek P, Levitsky H, Brose K, Jackson V, Hamada H, Pardoll D, Mulligan RC (1993) Vaccination with irradiated tumor cells engineered to secrete murine granulocyte-macrophage colony-stimulating factor stimulates potent, specific, and long-lasting anti-tumor immunity. Proc Natl Acad Sci USA 90: 3539 
17. D’Urso CM, Wang Z, Cao Y, Tatake R, Zeff RA, Ferrone S (1991) Lack of HLA class I antigen expression by cultured melanoma cells FO- 1 due to a defect in $\beta 2 \mathrm{~m}$ gene expression. J Clin Invest 87: 284

18. Farrar MA, Schreiber RD (1993) The molecular cell biology of interferon- $\gamma$ and its receptor. Annu Rev Immunol 11: 571

19. Fearon ER, Pardoll DM, Itaya T, Golumbek P, Levitsky HI, Simons JW, Karasuyama H, Volgelstein B, Frost P (1990) Interleukin-2 production by tumor cells bypasses $\mathrm{T}$ helper function in the generation of an antitumor response. Cell 60: 397

20. Felgner JH, Kumar R, Sridhar CN, Wheeler CJ, Tsai YJ, Border R, Ramsey P, Martin M, Felgner PL (1994) Enhanced gene delivery and mechanism studies with a novel series of cationic lipid formulations. J Biol Chem 269: 2550

21. Felgner PL, Padek TR, Holm M, Roman R, Chan HW, Wenz M, Northrop JP, Ringold GM, Danielsen M (1987) Lipofection: a highly efficient, lipid-mediated DNA-transfection procedure. Proc Natl Acad Sci USA 84: 7413

22. Fenton RT, Sznol M, Luster DG, Taub DD, Longo DL (1995) A phase I trial of B7-transfected or parental lethally irradiated allogeneic melanoma cell lines to induce cell-mediated immunity against tumor-associated antigen presented by HLA-A2 or HLAA1 in patients with stage IV melanoma. Hum Gene Ther 6: 87

23. Ferradini L, Roman-Roman S, Azocar J, Avril MF, Viel S, Triebel F, Hercend T (1992) Analysis of T-cell receptor $\alpha / \beta$ variability in lymphocytes infiltrating a melanoma metastasis. Cancer Res 52: 4649

24. Ferradini L, Mackensen A, Genevee C, Bosq J, Duvillard P, Avril MF, Hercend T (1993) Analysis of T cell receptor variability in tumor-infiltrating lymphocytes from a human regressive melanoma: evidence for in situ $\mathrm{T}$ cell clonal expansion. J Clin Invest 91: 1183

25. Ferrone S, Marincola FM (1995) Loss of HLA class I antigen by melanoma cells: molecular mechanisms, functional significance and clinical relevance. Immunol Today 16: 487

26. Floutsis G, Ulsh L, Ladisch S (1989) Immunosuppressive activity of human neuroblastoma tumor gangliosides. Int J Cancer 43: 6

27. Gansbacher B, Houghton A, Livingston P, Minasian L, Rosenthal F, Gilboa E, Golde D, Oettgen H, Steffens T, Yang SY, Wong G (1992) A pilot study of immunization with HLA-A2 matched allogeneic melanoma cells that secrete interleukin-2 in patients with metastatic melanoma. Hum Gene Ther 3: 677

28. Gansbacher B, Motzer R, Houghton A, Gilboa E, Bander N, Golde D, Minasian L, Gastl G, Rosenthal F, Scheinfeld J, Yang SY, Wong G, Reuter V, Livingston P, Bosl G, Nanus D, Fair WR (1992) A pilot study of immunization with interleukin-2 secreting allogeneic HLA-A2 matched renal cell carcinoma cells in patients with advanced renal cell carcinoma. Hum Gene Ther 3: 691

29. Gao X, Huang L (1991) A novel cationic liposome reagent for efficient transfection of mammalian cells. Biochem Biophys Res Commun 179: 280

30. Gilboa E, Lyerly HK, Vieweg J, Saito S (1994) Immunotherapy of cancer using cytokine gene-modified tumor vaccines. Semin Cancer Biol 5: 409

31. Goedegebuure PS, Zuber M, Leonard-Vidal L, Burger UL, Cusak JC Jr, Chang MP, Douville LM, Eberlein TJ (1994) Reactivation of murine tumor-infiltrating lymphocytes with solid-phase anti-CD3 antibody: in vitro cytokine production is associated with in vivo efficacy. Surg Oncol 3: 79

32. Gorman C, Padmanabhan R, Howard BH (1983) High efficiency DNA-mediated transformation of primate cells. Science 221: 551

33. Halapi E, Yamamoto Y, Juhlin C, Jeddi-Tehrani M, Grunewald J, Andersson R, Hising C, Masucci G, Mellstedt H, Kiessling R (1993) Restricted T cell receptor V- $\beta$ and J- $\beta$ usage in T cells from interleukin-2-cultured lymphocytes of ovarian and renal carcinomas. Cancer Immunol Immunother 36: 191

34. Hammerling GJ, Klar D, Katzav S, Segal S, Feldman M, Wallich R, Hammerling A (1985) Manipulation of metastasis and tumour growth by transfection with histocompatibility class I genes. J Immunogenet 13: 153
35. Hersh EM, Akporiaye E, Harris D, Stopek AT, Unger EC, Warneke JA (1994) Phase I study of immunotherapy of malignant melanoma by direct gene transfer. Hum Gene Ther 5: 1371

36. Holden CA, Sadisen AR, McDonald DM (1983) Absence of human leukocyte antigen molecules in skin tumors and some cutaneous appendages: evidence using monoclonal antibodies. J Am Acad Dermatol 9: 867

37. Hui K, Grosveld F, Festenstein H (1984) Rejection of transplantable AKR leukaemia cells following MHC DNA-mediated cell transformation. Nature 311: 750

38. Isakov N, Katza S, Feldman M, Segal S (1983) Loss of expression of transplantation antigens encoded by the $\mathrm{H}-2 \mathrm{~K}$ locus on Lewis lung carcinoma cells and its relevance to the tumor's metastatic properties. J Natl Cancer Inst 71: 139

39. Johnson CS, Chang MJ, Thurlow SM, Pourbohloul SC, Furmanski P (1990) Immunotherapeutic approaches to leukemia: the use of the Friend virus-induced erythroleukemia model system. Cancer Res 50: 5682

40. June CH, Bluestone JA, Nadler LM, Thompson CB (1994) The B7 and $\mathrm{CD} 28$ receptor families. Immunol Today 15: 321

41. Kawakami Y, Nishimura MI, Restifo NP, Topalian SL, O'Neil BH, Shilyansky J, Yannelli JR, Rosenberg SA (1993) T-cell recognition of human melanoma antigens. J Immunother 14: 88

42. Keilholz U, Scheibenbogen C, Stoelben E, Saeger HD, Hunstein W (1994) Immunotherapy of metastatic melanoma with interferonalpha and interleukin-2: pattern of progression in responders and patients with stable disease with or without resection of residual lesions. Eur J Cancer 30A: 955

43. Klein J, Juretic A, Baxevanis CN, Nagy ZA (1981) The traditional and a new version of the mouse H-2 complex. Nature 291: 455

44. Kradin RL, Lazarus DS, Dubinett SM (1989) Tumor-infiltrating lymphocytes and interleukin-2 in treatment of advanced cancer. Lancet I: 577

45. Kruit WH, Goey SH, Calabresi F, Lindemann A, Stahel RA, Poliwoda H, Osterwalder B, Stoter G (1995) Final report of a phase II study of interleukin 2 and interferon alpha in patients with metastatic melanoma. Br J Cancer 71: 1319

46. Lindahl P, Leary P, Gresser I (1973) Enhancement by interferon of the expression of surface antigens on murine leukemia L 1210 cells. Proc Natl Acad Sci USA 70: 2785

47. Lindahl P, Gresser I, Leary P, Tovey M (1976) Interferon treatment of mice: enhanced expression of histocompatibility antigens on lymphoid cells. Proc Natl Acad Sci USA 73: 1284

48. Ljunggren H-G, Karre K (1986) Experimental strategies and interpretations in the analysis of changes in MHC gene expression during tumour progression. Opposing influences of $\mathrm{T}$ cell and natural killer mediated resistance? J Immunogenet 13: 141

49. Lotze MT, Grum EA, Mazumdo A, Strausser L, Rosenberg SA (1981) Lysis of fresh and cultured autologous tumor by human lymphocytes cultured in T-cell growth factor. Cancer Res 41: 4420

50. Mackensen A, Ferradini L, Carcelain G, Triebel F, Faure F, Viel S, Hercend T (1993) Evidence for in situ amplification of cytotoxic T-lymphocytes with antitumor activity in a human regressive melanoma. Cancer Res 53: 3569

51. Mackiewicz A, Gorny A, Laciak M, Malicki J, Murawa P, Nowak J, Wiznerowicz M, Hawley RG, Heinrich PC, Rose-John S (1995) Gene therapy of human melanoma: immunization of patients with autologous tumor cells admixed with allogeneic melanoma cells secreting IL-6 and soluble IL- 6 receptor. Hum Gene Ther 6: 805

52. Matzinger P, Bevan MJ (1977) Why do so many lymphocytes respond to major histocompatibility antigens? Cell Immunol 29: 1

53. Melani C, Chiodoni C, Arienti F, Maccalli C, Sule-Suso J, Anichini A, Colombo MP, Parmiani G (1994) Cytokine gene transduction in tumor cells: interleukin (IL)-2 or IL-4 gene transfer in human melanoma cells. Nat Immun 13: 76

54. Mitchell MS, Jakowatz J, Harel W, Dean G, Stevenson L, Boswell WD, Groshen S (1994) Increased effectiveness of interferon $\alpha-2 \beta$ following active specific immunotherapy for melanoma. J Clin Oncol 12: 402 
55. Morton DL, Eilber FR, Holmes EC (1974) BCG immunotherapy of malignant melanoma: summary of a seven-year experience. Ann Surg 180: 635

56. Moss PAH, Rosenberg WMC, Bell JI (1992) The human T cell receptor in health and disease. Annu Rev Immunol 10: 71

57. Mule JJ, Krosnick A, Rosenberg SA (1989) IL-4 regulation of murine lymphokine-activated killer activity in vitro. Effects on the IL-2-induced expansion, cytotoxicity, and phenotype of lymphokine-activated killer effectors. J Immunol 142: 726

58. Nabel EG, Plautz G, Boyce FM, Stanley JC, Nabel GJ (1989) Recombinant gene expression in vivo within endothelial cells of the arterial wall. Science 244: 1342

59. Nabel EG, Plautz G, Nabel GJ (1990) Site-specific gene expression in vivo by direct gene transfer into the arterial wall. Science 249: 1285

60. Nabel EG, Gordon D, Yang Z, Xu L, San H, Plautz GE, Wu BY, Gao X, Huang L, Nabel GJ (1992) Gene transfer in vivo with DNA-liposome complexes: lack of autoimmunity and gonadal localization. Hum Gene Ther 3: 649

61. Nabel EG, Plautz G, Nabel GJ (1992) Transduction of a foreign histocompatibility gene into the arterial wall induces vasculitis. Proc Natl Acad Sci USA 89: 5157

62. Nabel EG, Yang ZY, Plautz G, Forough R, Zhan X, Haudenschild CC, Maciag T, Nabel GJ (1993) Recombinant fibroblast growth factor-1 promotes intimal hyperplasia and angiogenesis in arteries in vivo. Nature 362: 844

63. Nabel GJ, Chang A, Nabel EG, Plautz G, Fox BA, Huang L, Shu S (1992) Clinical protocol: immunotherapy of malignancy by in vivo gene transfer into tumors. Hum Gene Ther 3: 399

64. Nabel GJ, Nabel EG, Yang Z-Y, Fox BA, Plautz GE, Gao X, Huang L, Shu S, Gordon D, Chang AE (1993) Direct gene transfer with DNA-liposome complexes in melanoma: Expression, biologic activity, and lack of toxicity in humans. Proc Natl Acad Sci USA 90: 11307

65. Nabel GJ, Chang AE, Nabel EG, Plautz GE, Ensminger W, Fox BA, Felgner P, Shu S, Cho K (1994) Clinical protocol: immunotherapy for cancer by direct gene transfer into tumors. Hum Gene Ther 5: 57

66. Nabel GJ, Gordon D, Bishop DK, Nickoloff BJ, Yang ZY, Aruga A, Cameron MJ, Nabel EG, Chang AE (1996) Immune response in human melanoma after transfer of an allogeneic class I major histocompatibility complex gene with DNA-liposome complexes. Proc Natl Acad Sci USA

67. Old LJ (1985) Tumor necrosis factor (TNF). Science 230: 630

68. Old LJ (1987) Tumour necrosis factor. Polypeptide mediator network. Nature 326: 330

69. O'Mahony AM, O'Sullivan GC, O'Connell J, Cotter TG, Collins JK (1993) An immune suppressive factor derived from esophageal squamous carcinoma induces apoptosis in normal and transformed cells of lymphoid lineage. J Immunol 151: 4847

70. Osanto S, Brouwenstyn N, Vassen N, Figdor CG, Melief CJM, Schrier PI (1993) Immunization with IL-2 transfected melanoma cells. Hum Gene Ther 4: 323

71. Peoples GE, Davey MP, Goedegebuure PS, Schoof DD, Eberlein TJ (1993) T cell receptor V $\beta 2$ and V $\beta 6$ mediate tumor-specific cytotoxicity by tumor-infiltrating lymphocytes in ovarian cancer. J Immunol 151: 5472

72. Plautz GE, Yang Z, Wu B, Gao X, Huang L, Nabel GJ (1993) Immunotherapy of malignancy by in vivo gene transfer into tumors. Proc Natl Acad Sci USA 90: 4645

73. Poppema S, Brocker EB, De Leij L, Terbrack D, Visscher T, ter Harr A, Macher E, The TH, Sorg C (1983) In situ analysis of the mononuclear cell infiltrate in primary malignant melanoma of the skin. Clin Exp Immunol 51: 77

74. Powell MB, Conta BS, Horowitz M, Ruddle H (1985) The differential inhibitory effect of lymphotoxin and immune interferon on normal and malignant lymphoid cells. Lymphokine Res 4: 13

75. Puisieux I, Even J, Pannetier C, Jotereau F, Favrot M, Kourilsky P (1994) Oligoclonality of tumor-infiltrating lymphocytes from human melanomas. J Immunol 153: 2807
76. Restifo NP, Esquivel F, Kawakami Y, Yewdell JW, Mule JJ, Rosenberg SA, Bennink JR (1993) Identification of human cancers deficient in antigen processing. J Exp Med 177: 265

77. Restifo NP, Kawakami Y, Marincola F, Shamamian P, Taggarse A, Esquivel F, Rosenberg SA (1993) Molecular mechanisms used by tumors to escape immune recognition: immunogenetherapy and the cell biology of major histocompatibility complex class I. J Immunother 14: 182

78. Rosenberg SA (1992) Immunization of cancer patients using autologous cancer cell modified by insertion of the gene for tumor necrosis factor. Hum Gene Ther 3: 57

79. Rosenberg SA, Mule JJ, Spiess PJ (1985) Regression of established pulmonary metastases and subcutaneous tumor mediated by the systemic administration of high-dose recombinant interleukin-2. J Exp Med 161: 1169

80. Rosenberg SA, Packard BS, Aebersold PM, Solomon D, Topalian SL, Toy ST, Simon P, Lotze MT, Yang JC, Seipp CA, Simpson C, Carter C, Bock S, Schwartzentruber D, Wei JP, White DE (1988) Use of tumor-infiltrating lymphocytes and interleukin-2 in the immunotherapy of patients with metastatic melanoma. $\mathrm{N}$ Engl J Med 319: 1676

81. Rosenberg SA, Lotze MT, Yang JC, Aebersold PM, Linehan WM, Seipp CA, White DE (1989) Experience with the use of high-dose interleukin- 2 in the treatment of 652 cancer patients. Ann Surg 210: 474

82. Rosenberg SA, Abersold P, Cornetta K, Kasid A, Morgan RA, Moen R, Karson EM, Lotze MT, Yang JC, Topalian SL, Merino MJ, Culver K, Miller AD, Blaese RM, Anderson WF (1990) Gene transfer into humans - immunotherapy of patients with advanced melanoma, using tumor-infiltrating lymphocytes modified by retroviral gene transduction. N Engl J Med 323: 570

83. Rosenberg SA, Yang JC, Topalian SL, Schwartzentruber DJ, Weber JS, Parkinson DR, Seipp CA, Einhorn JH, White DE (1994) Treatment of 283 consecutive patients with metastatic melanoma or renal cell cancer using high-dose bolus interleukin 2. JAMA 271: 907

84. Rosenberg SA, Yannelli JR, Yang JC, Topalian SL, Schwartzentruber DJ, Weber JS, Parkinson DR, Seipp CA, Einhorn JH, White DE (1994) Treatment of patients with metastatic melanoma with autologous tumor-infiltrating lymphocytes and interleukin 2. J Natl Cancer Inst 86: 1159

85. Roszman T, Elliott L, Brooks W (1991) Modulation of T-cell function by gliomas. Immunol Today 12: 370

86. San H, Yang Z, Pompili VJ, Jaffe ML, Plautz GE, Xu L, et al (1993) Safety and short-term toxicity of a novel cationic lipid formulation for human gene therapy. Hum Gene Ther 4: 781

87. Schmidt-Wolf IGH, Hugh D, Neubauer A, Wittig B (1994) IL-7 gene transfer in patients with metastatic colon carcinoma, renal cell carcinoma, melanoma, or with lymphoma. Hum Gene Ther 5: 1161

88. Schwartzentruber DJ, Hom SS, Dadmarz R, White DE, Yannelli JR, Steinberg SM, Rosenberg SA, Topalian SL (1994) In vitro predictors of therapeutic response in melanoma patients receiving tumor-infiltrating lymphocytes and interleukin-2. J Clin Oncol 12: 1475

89. Seigler HF, Darrow TL, Abdel-Wahab Z, Gangavalli R, Barber J (1994) A phase I trial of human gamma interferon transduced autologous tumor cells in patients with disseminated malignant melanoma. Hum Gene Ther 5: 761

90. Sensi M, Salvi S, Castelli C, Maccalli C, Mazzocchi A, Mortarini R, Nicolini G, Herlyn M, Parmiani G, Anichini A (1993) $\mathrm{T}$ cell receptor (TCR) structure of autologous melanoma-reactive cytotoxic T lymphocyte (CTL) clones: tumor-infiltrating lymphocytes overexpress in vivo the TCR $\beta$ chain sequence used by an HLA-A2-restricted and melanocyte-lineage-specific CTL clone. J Exp Med 178: 1231

91. Shoskes DA, Wood KJ (1994) Indirect presentation of MHC antigens in transplantation. Immunol Today 15: 32

92. Shu S, Rosenberg SA (1985) Adoptive immunotherapy of newly induced murine sarcomas. Cancer Res 45: 1657 
93. Skoskiewicz MJ, Colvin RB, Schneeberger EE, Russell PS (1985) Widespread and selective induction of major histocompatibility complex-determined antigens in vivo by $\gamma$ interferon. J Exp Med 162: 1645

94. Spiess PJ, Yang JC, Rosenberg SA (1987) In vivo antitumor activity of tumorinfiltrating lymphocytes expanded in recombinant interleukin-2. J Natl Cancer Inst 79: 1067

95. Straten PT, Scholler J, Hou-Jensen K, Zeuthen J (1994) Perferential usage of T-cell receptor $\alpha \beta$ variable regions among tumorinfiltrating lymphocytes in primary human malignant melanomas. Int J Cancer 56: 78

96. Stewart MJ, Plautz GE, Del Buono L, Yang ZY, Xu L, Gao X, Huang L, Nabel EG, Nabel GJ (1992) Gene transfer in vivo with DNA-liposome complexes: safety and acute toxicity in mice. Hum Gene Ther 3: 267

97. Tanaka K, Isselbacher KJ, Khoury G, Jay G (1985) Reversal of oncogenesis by the expression of a major histocompatibility complex class I gene. Science 228: 26

98. Tepper RI, Pattengale PK, Leder P (1989) Murine interleukin-4 displays potent anti-tumor activity in vivo. Cell 57: 503

99. Topalian SL, Kasid A, Rosenberg SA (1990) Immunoselection of a human melanoma resistant to specific lysis by autologous tumorinfiltrating lymphocytes: possible mechanisms for immunotherapeutic failures. J Immunol 144: 4487

100. Townsend SE, Allison JP (1993) Tumor rejection after direct costimulation of CD8+ T cells by B7-transfected melanoma cells. Science 259: 368
101. Van Gool SW, Barcy S, Devos S, Vandenberghe P, Ceuppens JL, Thielemans K, de Boer M (1995) CD80 (B7-1) and CD86 (B7-2): potential targets for immunotherapy? Res Immunol 146: 183

102. Vogelzang NJ, Lestingi TM, Sudakoff G (1994) Phase I study of immunotherapy of metastatic renal cell carcinoma by direct gene transfer into metastatic lesions. Hum Gene Ther 5: 1357

103. Wallich R, Bulbuc N, Hammerling GJ, Katzav S, Segal S, Feldman M (1985) Abrogation of metastatic properties of tumour cells by de novo expression of $\mathrm{H}-2 \mathrm{~K}$ antigens following $\mathrm{H}-2$ gene transfection. Nature 315: 301

104. Wang Z, Cao Y, Albino AP, Zeff AR, Houghton A, Ferrone S (1993) Lack of HLA class I antigen expression by melanoma cells SK-Mel-33 caused by a reading frameshift in $\beta 2$-microglobulin messenger RNA. J Clin Invest 91: 684

105. Weidmann E, Elder EM, Trucco M, Lotze MT, Whiteside TL (1993) Usage of T-cell receptor $V \beta$ chain genes in fresh and cultured tumor-infiltrating lymphocytes from human melanoma. Int J Cancer 54: 383

106. Yoshizawa H, Chang AE, Shu S (1991) Specific adoptive immunotherapy mediated by tumor-draining lymph node cells sequentially activated with anti-CD3 and IL-2. J Immunol 147: 729

107. Zbar B, Bernstein ID, Rapp HJ (1971) Suppression of tumor growth at the site of infection with living bacillus CalmetteGuerin. J Natl Cancer Inst 46: 831 